\title{
Compound heterozygosity for hemoglobin D and hemoglobin $\mathrm{E}$
}

\author{
Mohammad Mizanur Rahman, Lutfunnahar Khan, Masuda Begum, Debashish Saha and \\ Arif Ahmed Khan
}

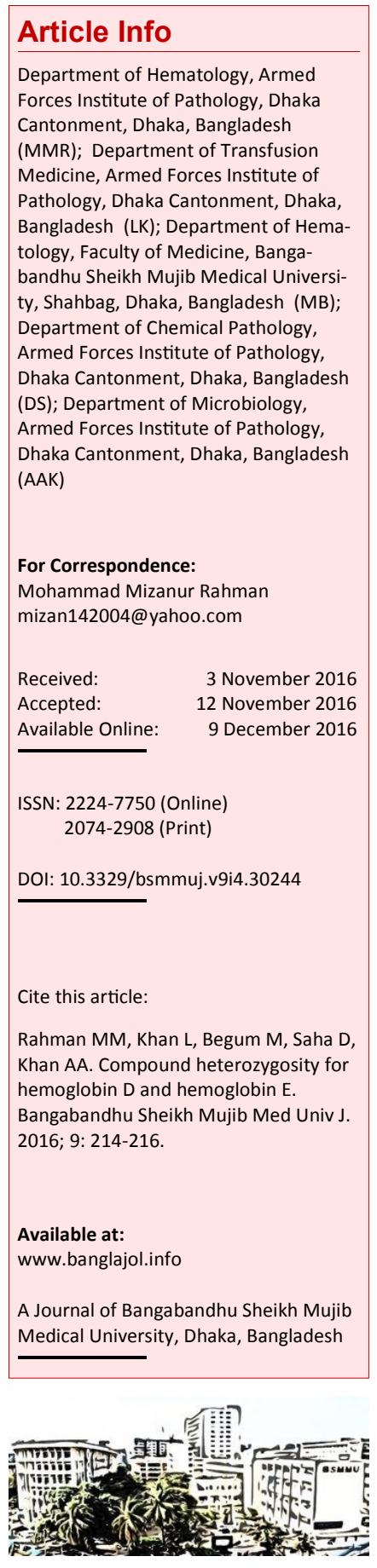

\section{Abstract}

We present two cases of compound heterozygous state for hemoglobin $(\mathrm{Hb}) \mathrm{D}$ and $\mathrm{HbE}$ who reported to the hospital for fever and incidentally found moderate microcytic hypochromic anemia. Later on they were investigated by capillary hemoglobin electrophoresis. Capillary $\mathrm{Hb}$ electrophoresis revealed compound heterozygous state for hemoglobin D and hemoglobin E. On family screening, father of one patient turned out to be $\mathrm{HbD}$ trait and mother as $\mathrm{HbE}$ trait. Due to unavailability of parents and siblings of other patient, family screening was not possible. Compound or double heterozygous state for $\mathrm{HbD}$ and $\mathrm{HbE}$ is rare. There are only six published reported cases of such double heterozygous state for $\mathrm{HbD}$ and $\mathrm{HbE}$ in Southeast Asia. Marriage between third degree relatives, which are more common among Muslims as well as inter caste marriages, common in some states of India have resulted into this compound heterozygous condition. Such double heterozygous case is clinically silent as compared to $\mathrm{HbE} /$ beta thalassemia or $\mathrm{HbD} /$ beta thalassemia.

\section{Introduction}

Amplitude of abnormal hemoglobins varies notably with geographic location and racial groups. Abnormal hemoglobins or hemoglobinopathies are the most common genetic disorders among the people residing in Southeast Asia.1 The ethnic origins of people living in these countries are very heterogeneous. In Southeast Asia, a-thalassemia, $\beta$ thalassemia and hemoglobinopathies such as hemoglobin $\mathrm{E}(\mathrm{HbE})$, hemoglobin $\mathrm{D}(\mathrm{HbD})$, hemoglobin $\mathrm{S}(\mathrm{HbS})$ and hemoglobin $\mathrm{C}(\mathrm{HbC})$ are prevalent. 2 These four hemoglobinopathies, $\mathrm{HbE}, \mathrm{HbS}, \mathrm{HbD}$ and $\mathrm{HbC}$; each affects millions worldwide. $1 \mathrm{HbE}, \mathrm{HbD}$ and $\mathrm{HbS}$ are widely prevalent and occur in several populations in different parts of the country.

$\mathrm{HbE}\left(\beta^{26 \mathrm{Glu}} \rightarrow \mathrm{Lys}\right)$ is most prevalent in Southeast Asia, affecting more than $50 \%$ of the population in eastern Thailand (Surin Province) and from 20 to $45 \%$ in other parts of Thailand and in Cambodia, Laos and Burma. A somewhat lower prevalence, 3 to $8 \%$, is found in Vietnam. An estimated 30 million people may carry $\mathrm{HbE}$ gene in this region. 4 From the mainland, the gene spread southward to parts of Indonesia but the incidence is low in Indian subcontinent to the West and in China to the Northeast.1 In Bangladesh, the prevalence of $\mathrm{HbE}$ gene is not studied but it is expected to be the same of India where an average $\mathrm{HbE}$ gene frequency has been found to be $10.9 \%$ in Northeastern states of India. $\underline{5}$

The usual ethnic origin of $\mathrm{HbD}\left(\beta^{121 \mathrm{Glu} \rightarrow \mathrm{Gln}}\right)$ is in Punjabis, Northern European, Greek, Turkish, Yugoslav, Afro-American, Afro-Caribbean and Chinese.6 Its prevalence is greatest (2\%) among the Sikhs of the Punjab in India as well as in nearby Gujarat $(1 \%)$ and Iran.1The prevalence of $\mathrm{HbD}$ gene in Bangladesh is also not known but in comparison to $\mathrm{HbE}$, it is relatively rare.

Here, we report two cases of double heterozygous state for $\mathrm{HbE}$ and $\mathrm{HbD}$ which is rare in this country. The aim of reporting these two cases is to apprise the stakeholders that such cases are prevalent in our community, though rare but their treatment is simple on one hand and on the other hand genetic counseling is important for determining the reproductive risk of the family.

\section{Case Report}

\section{Case 1}

A 5 year old male boy residing in Dhaka city near Dhaka Cantonment reported to a hematologist as a part of family screening for inherited hemoglobin disorders when his complete blood count, done for trivial illness, showed microcytic hypochromic blood picture and hematologist advised his parents to repeat 


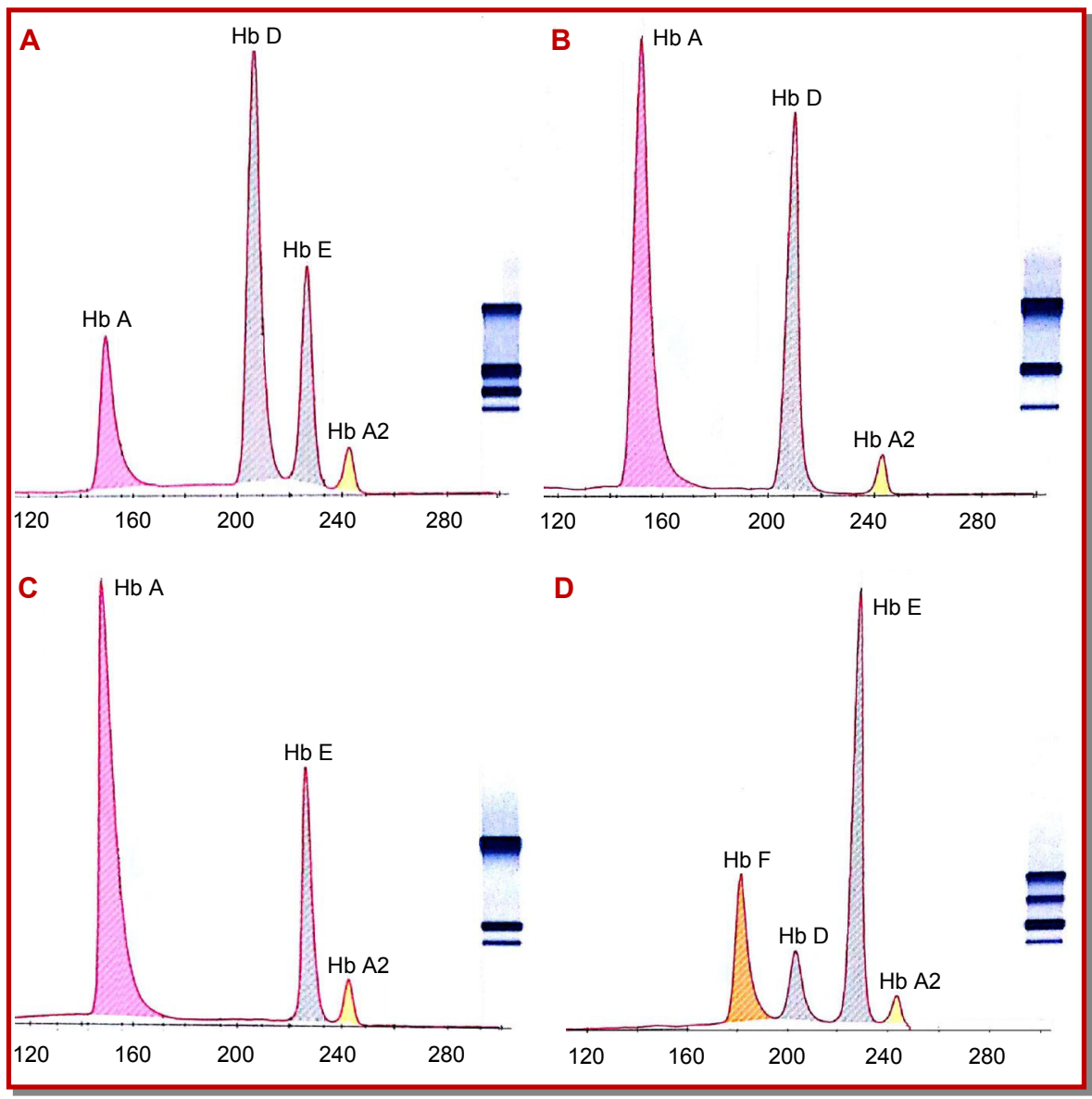

Figure 1: Hemoglobin pattern of case 1 (A), his father (B), mother (C) and case 2 (D) on capillary hemoglobin electrophoresis

complete blood count and do capillary hemoglobin electrophoresis for their child. During interview, history and physical examination of the boy, no abnormality was detected. The complete blood count parameters were hemoglobin $12.1 \mathrm{~g} / \mathrm{dL}, \mathrm{RBC}$ count $5.3 \times 1012 / \mathrm{L}$, mean corpuscular volume

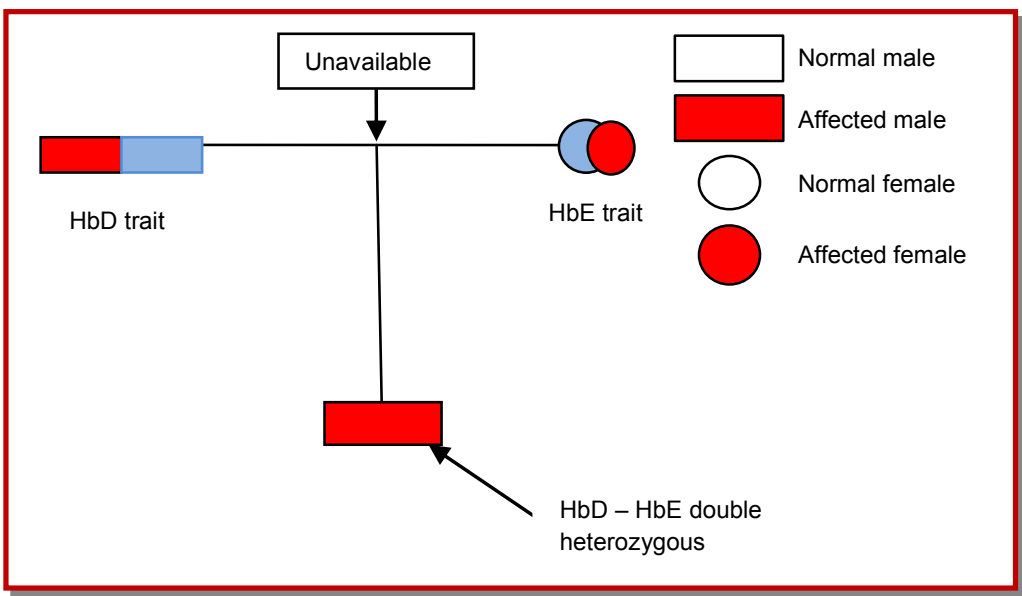

Figure 2: Family pedigree of the boy (case 1)
(MCV) $64.2 \mathrm{fL}$, mean corpuscular hemoglobin $(\mathrm{MCH}) 22.8 \mathrm{pg}$, mean corpuscular hemoglobin concentration (MCHC) 35.5 $\mathrm{g} / \mathrm{dL}$, red cell distribution width (RDW) $15.4 \%$ and other parameters were not remarkable and capillary $\mathrm{Hb}$ electrophoresis revealed $\mathrm{HbA} 21.3 \%$, $\mathrm{HbD} 52.3 \%$, $\mathrm{HbE} 22.5 \%$ and $\mathrm{HbA}_{2} 3.9 \%$ (Figure 1A) indicating the diagnosis of $\mathrm{HbD}-\mathrm{HbE}$ double heterozygous. After getting such hemoglobin patterns of the child, the parents were requested to report for further evaluation.

At the same time, history, physical examination and evaluation of previous investigations of both parents were done. His father, 40 years old male had no remarkable findings on history and physical examination except mild anemia. His complete blood count revealed hemoglobin $11.2 \mathrm{~g} / \mathrm{dL}$, RBC count $5.0 \mathrm{x}$ 1012/L, MCV 90.1 fL, MCH 22.4 pg, MCHC $31.5 \mathrm{~g} / \mathrm{dL}$, RDW 14.8\% and other parameters were normal. His capillary hemoglobin electrophoresis showed $\mathrm{HbA}$ $60.4 \%, \mathrm{HbD} 36.6 \%$ and $\mathrm{HbA}_{2} 3.0 \%$ suggesting $\mathrm{HbD}$ trait (Figure $1 \mathrm{~B}$ ). His mother, 31 years old female complained of weakness during history taking and on physical examination she was found moderately anemic. Her complete blood count showed hemoglobin $7.3 \mathrm{~g} / \mathrm{dL}, \mathrm{RBC}$ count $4.2 \times 10^{12} / \mathrm{L}, \mathrm{MCV} 83.8 \mathrm{fL}, \mathrm{MCH} 16.9$ pg, MCHC $30.5 \mathrm{~g} / \mathrm{dL}$, RDW 13.9\% and other parameters of complete blood count were normal. Her capillary hemoglobin electrophoresis disclosed $\mathrm{HbA} 70.5 \%$, $\mathrm{HbE} \mathrm{25.5 \%}$ and $\mathrm{HbA}_{2} 4.0 \%$ indicating the diagnosis $\mathrm{HbE}$ trait (Figure 1C).

Analysis of the investigations of the family confirms that the boy is a case of rare compound heterozygous state for $\mathrm{HbD}$ and $\mathrm{HbE}$. His family pedigree is shown in Figure 2 and parameters of complete blood count of the family members are shown in Table I.

\section{Case 2}

A 65 years old female was referred for complete blood count and capillary hemoglobin electrophoresis. Her complete blood count revealed $\mathrm{Hb} 7.0$ $\mathrm{g} / \mathrm{dL}, \mathrm{RBC}$ count $4.3 \times 10^{12} / \mathrm{L}, \mathrm{MCV} 57.3 \mathrm{fL}, \mathrm{MCH}$ $16.3 \mathrm{pg}, \mathrm{MCHC} 28.4 \mathrm{~g} / \mathrm{dL}$, RDW $18.7 \%$, total leucocyte count $25.8 \times 10^{9} / \mathrm{L}$ and platelet count $873.0 \times 10^{9} / \mathrm{L}$. Comment was suggestive of hereditary hemolytic anemia. Capillary hemoglobin electrophoresis transpired $\mathrm{HbF} 26.1 \%, \mathrm{HbD} 12.2 \%$, $\mathrm{HbE} 58.1 \%$ and $\mathrm{HbA}_{2} 3.6 \%$ and the comment was hemoglobin D-E double heterozygous (Figure 1D). As the patient's parents and siblings were not 
Table I

Hematological parameters of the patient and his parents of case 1

\begin{tabular}{|lcccccccccc|c|}
\hline Relation & $\begin{array}{c}\mathrm{Hb}(\mathrm{g} / \\
\mathrm{dL})\end{array}$ & $\begin{array}{c}\mathrm{RBC} \text { count } \\
\left(\mathrm{X} 10^{12} / \mathrm{L}\right)\end{array}$ & $\begin{array}{c}\mathrm{MCV} \\
(\mathrm{fL})\end{array}$ & $\begin{array}{c}\mathrm{MCH} \\
(\mathrm{pg})\end{array}$ & $\begin{array}{c}\mathrm{MCHC} \\
(\mathrm{g} / \mathrm{dL})\end{array}$ & $\begin{array}{c}\mathrm{RDW} \\
(\%)\end{array}$ & $\begin{array}{c}\mathrm{HbA} \\
(\%)\end{array}$ & $\begin{array}{c}\mathrm{HbA}_{2} \\
(\%)\end{array}$ & $\begin{array}{c}\mathrm{HbE} \\
(\%)\end{array}$ & $\begin{array}{c}\mathrm{HbD} \\
(\%)\end{array}$ & $\begin{array}{c}\mathrm{HbF} \\
(\%)\end{array}$ \\
\hline Patient & 12.1 & 5.3 & 64.2 & 22.8 & 35.5 & 15.4 & 21.3 & 3.9 & 22.5 & 52.3 & $\mathrm{Nil}$ \\
Father & 11.1 & 5.0 & 90.1 & 22.4 & 31.5 & 14.8 & 60.4 & 3.0 & - & 36.6 \\
Mother & 7.3 & 4.2 & 83.8 & 16.9 & 30.5 & 13.9 & 70.5 & 4.0 & 25.5 & - \\
\hline
\end{tabular}

available, so her pedigree analysis was not possible.

\section{Discussion}

These two are probably the first reported cases of double heterozygous state for $\mathrm{HbE}$ and $\mathrm{HbD}$ from Bangladesh. $\mathrm{HbE}$ is prevalent in this country but exact frequency of $\mathrm{HbE}$ gene carriers is not known. $\mathrm{HbE}$ trait and $\mathrm{HbE}$ disease is distributed equally all over the country. $\mathrm{HbD}$ is rare in this country. A very few cases of heterozygous $\mathrm{HbD}$ trait were detected so far by capillary hemoglobin electrophoresis.

Very few reports are available about compound heterozygous state for $\mathrm{HbE}$ and $\mathrm{HbD}$. We could find only three published reports with cases of $\mathrm{Hb}$ $\mathrm{D}$ and $\mathrm{Hb} \mathrm{E}$ possibly due to their prevalence in people with different geographical location and ethnicity. $6-8$ The hematological parameters in those reported six patients had normal or slightly reduced hemoglobin (range: 7.5-15.3 g/dL), low MCV (range: 63-88.4 fL), low MCH (range: 19.1$24.5 \mathrm{pg}$ ), $\mathrm{HbD}$ (range: 61.2-65.5\%), $\mathrm{HbE}$ (range: 26.7 $-29.6 \%$ ) and normal $\mathrm{HbF}$ (range: 0.6-1.7\%). 6 The hematological parameters in the present reported cases are also similar to Gupta et al (2015).6 With these two cases in our report, the total published reported cases is now eight.

\section{Conclusion}

Patients with compound heterozygous state for $\mathrm{HbE}$ and $\mathrm{HbD}$ are almost clinically asymptomatic and are usually detected during routine checkup when they are found mildly to moderately anemic and blood film shows the features of microcytic hypochromic anemia or hereditary hemolytic anemia. In our two cases patients were moderately anemic and passed unnoticed.

\section{Ethical Issue}

Written and informed consent were taken from the patients as well as guardian of the patient for publishing this article.

\section{References}

1. Lukens JN. The abnormal haemoglobins: General principles. In: Wintrobe's Clinical Hematology, Lee G, Foerster J, Lukes J, Paraskevas F, Greer PJ, Rodgers MG (eds). 10 th ed. Vol 1. Baltimore, Williams and Wilkins, pp 1333-43.

2. Fucharoen S, Winichagoon P. Haemoglobinopathies in Southeast Asia. Indian J Med Res. 2011; 134: 498-506.

3. Balgir RS, Sharma SK. Distribution of sickle cell haemoglobin in India. Indian J Hemat. 1988; 6: 1-4.

4. Flatz G. Hemoglobin E: Distribution and population dynamics. Hum Genet. 1967; 3: 189-234.

5. Balgir RS. Genetic epidemiology of the three predominant abnormal haemoglobins in India. J Assoc Phys India. 1996; 44: 25-28.

6. Gupta SK, Dass J, Saxena R. A rare case of double heterozygous state for $\mathrm{HbD}$ and $\mathrm{HbE}$. Indian J Pathol Microbiol. 2015; 58: 126-27.

7. Sharma K, Gogi S, Dutta R, Mahanta J. HbD in a mongoloid non-tribal family: A report from northeast India. Curr Sci. 2003; 84: 752-53.

8. Edison ES, Shaji RV, Chandy M, Srivastava A. Interaction of $\mathrm{HbE}$ with other abnormal haemoglobins. Acta Haematol. 2011; 126: 246-54. 